\title{
Do informative leaflets affect pre-procedural anxiety and immediate pain after transforaminal epidural steroid injections? A prospective randomized controlled study
}

\author{
Bilgilendirme broşürleri işlem öncesi anksiyete seviyesi ve transforaminal epidural steroid \\ enjeksiyonu sonrası akut ağrı düzeyini etkiler mi? Prospektif randomize kontrollü bir çalışma
}

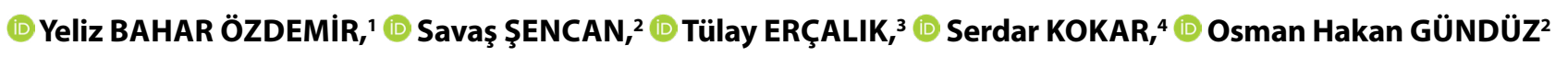

\begin{abstract}
Summary
Objectives: The aim of this study was to evaluate the effect of an informative leaflet provided to patients before a lumbar transforaminal epidural steroid injection (TFESI) on the level of immediate pain and pre-procedural anxiety.

Methods: A total of 166 patients were randomized into 2 groups: a group that received an explanatory leaflet (LG) and a control group. Both groups were given verbal information, while the LG was also given an illustrated leaflet describing the injection process. All of the patients were evaluated with the Hospital Anxiety and Depression Scale before the TFESI. The numerical rating scale and the Oswestry Disability Index (ODI) were used to assess disability and pain before and after the TFESI. Major complications that occurred before and during the procedure were recorded and analyzed.

Results: The patient characteristics were similar in both groups (age, body mass index, depression level, pre-procedural pain, and ODI). The anxiety level was also similar in both groups ( $p>0.05$ ). When both groups were evaluated at the first hour after the procedure, the numerical rating scale level of pain intensity was also similar $(p>0.05)$. No major complication was observed in either group.

Conclusion: The detailed leaflet did not affect the patients' pre-procedural anxiety or acute post-procedural pain level. However, the importance of informed consent and comprehensive information should not be overlooked.
\end{abstract}

Keywords: Anxiety; disc herniation; informative leaflet, low-back pain; lumbar radiculopathy; transforaminal epidural steroid injection.

\begin{abstract}
Özet
Amaç: Lomber radikülopati tedavisinde kullanılan transforaminal epidural steroid enjeksiyonu (TFESE) sonuçları, tedavi öncesi ayrıntılı bilgilendirmeden etkilenebilir. Bu çalışma lomber TFESI enjeksiyonundan önce verilen yazılı ve görsel bilgi broşürünün akut ağrı ve işlem öncesi anksiyete düzeyine etkisini değerlendirmeyi amaçlamıştır.

Gereç ve Yöntem: Yüz-altmış-altı hasta Broşür grubu (BG) ve kontrol olarak iki gruba randomize edildi. Her iki gruba sözlü bilgi verildi. BG'ye ayrıca enjeksiyon işlemini tarif eden yazılı ve görsel içerikli bir bilgi broşürü verildi. Tüm hastalar işlem öncesinde Hastane Anksiyete ve Depresyon Ölçeği ile anksiyete açısından değerlendirildi. Sayısal derecelendirme ölçeği ve Oswestry Disabilite İndeksi (ODI), TFESE'den önce ve sonra dizabilite düzeyi ve ağrı değerlendirmesi için kullanıldı. İşlem öncesi ve sırasında meydana gelen major komplikasyonlar kaydedildi.

Bulgular: Hastaların özellikleri her iki grupta da benzerdi (yaş, vücut kitle indeksi, işlem öncesi ağıı ve ODI seviyesi). Ayrıca, anksiyete varlığı her iki grupta da benzerdi $(p>0,05)$. Her iki grup işlemden sonraki ilk bir saatte değerlendirildiğinde NRS düzeyleri benzer olarak bulundu ( $p>0,05)$. Major bir komplikasyon gözlenmedi.

Sonuç: Ayrıntılı bilgilendirme formunun, hastaların enjeksiyon öncesi anksiyete düzeyi ve işlem sonrası akut ağrı seviyesi üzerine etkisi olmamıştır. Ancak, aydınlatılıı̧ onamın ve ayrıntılı bilgilendirmenin önemi göz ardı edilmemelidir.
\end{abstract}

'Department of Physical Medicine and Rehabilitation, Health Sciences University Sultan Abdulhamid Han Training and Research Hospital, İstanbul, Turkey

${ }^{2}$ Division of Pain Medicine, Department of Physical Medicine and Rehabilitation, Marmara University Faculty of Medicine, ístanbul, Turkey ${ }^{3}$ Department of Pain Medicine, Şişli Hamidiye Etfal Training and Research Hospital, İstanbul, Turkey ${ }^{4}$ Division of Pain Medicine, Department of Physical Medicine and Rehabilitation, İstanbul University-Cerrahpaşa, Cerrahpaşa Faculty of Medicine, İstanbul, Turkey

Submitted (Başvuru tarihi) 15.12.2019 Accepted after revision (Düzeltme sonrası kabul tarihi) 20.05.2020 Available online date (Online yayımlanma tarihi) 19.11.2020

Correspondence: Dr. Savas Sencan. Marmara Üniversitesi Tıp Fakültesi, Fiziksel Tıp ve Rehabilitasyon Anabilim Dalı, İstanbul, Turkey.

Phone: +90 - 216-657 0606 e-mail: savas-44@hotmail.com

(C) 2021 Turkish Society of Algology 


\section{Introduction}

Exchange of information is the basis of any doctorpatient relationship. The modern patient is eager to learn more about personal health and the procedures performed. ${ }^{[1]}$ They are expected to provide detailed information about the diseases, applied investigations, and treatment methods. This expectation requires both the ethical and legal requirements to ensure that patients receive high quality and adequate information. ${ }^{[2]}$ Patient information leaflets have become a routine in today's treatment practice to increase patient understanding and participation. [2] Information leaflets may prevent the limitation of the information transfer that may occur due to the time-constrained between the doctor and the patient. ${ }^{[1]}$ Previous studies have shown that patient information leaflets increase the patient's understanding of the treatment/research methods applied and facilitate decision-making. ${ }^{[2]}$ There are two main objectives of informing the patient. The first of which is to provide patient satisfaction, knowledge, and understanding and thus increase the benefit of treatment. The second objective is to reduce anxiety and pain levels to avoid negative consequences such as a major stress response. ${ }^{[3]}$ However, many doctors have assumed that providing information about the risks and complications of treatment modalities raises unnecessary and harmful concerns, reduces retention of information, and changes the doctorpatient relationship. ${ }^{[3]}$ At the same time, despite being one of the main communication tools, a variable written notification from time to time, it may be incomprehensible and irrelevant. Inadequate information, excessive information, time constraints, the inadequate format of presentation are some of the problems with written information. ${ }^{[2]}$

Lumbar radiculopathy is a very common disease that causes suffering and can affect the daily lives of all ages people. It is also one of the most common causes of low back pain. ${ }^{[4,5]}$ Transforaminal epidural steroid injection (TFESI) has been commonly preferred by patients who cannot benefit from the conservative intervention in the treatment of lumbosacral radiculopathic pain. ${ }^{[4,6]}$ This non-surgical intervention may be of concern to most patients, as it has never been heard before and is performed in a different environment (such as the operating room) than the outpatient setting.
Although the use of information leaflets given to patients prior to surgical or non-surgical interventions have not yet been standardized in each clinic, the effects on patients have recently been frequently researched. Researchers have begun to investigate patient education and the effects of written and visual information leaflets on anxiety, pain and treatment outcomes for patients undergoing surgery. [7,8] An informative leaflet or detailed information given prior to surgical intervention has been shown to be effective in reducing anxiety and pre-/postprocedural pain, ${ }^{[7,9]}$ but few studies are showing the effectiveness on TFESI. ${ }^{[3]}$ Within this information, the aim of the study was to evaluate the acute impact of written and visual standardized informative leaflets, provided in addition to verbal information on anxiety and pain in the patients with lumbosacral radiculopathy and hospitalized for TFESI.

\section{Material and Methods}

\section{Patient selection}

Patients with low back and leg pain and admitted to the pain medicine outpatient clinic were evaluated for 2 years (Between 2013 and 2015). Physical examination was performed, and lumbar imaging was investigated for all evaluated patients. Inclusion criteria were: (1) patients with lumbar radiculopathy, (2) failure of conservative approaches, (3) patients planned for TFESI for the first time. The exclusion criteria were as follows: (1) cases where fluoroscopy or epidural injection is contraindicated (E.g. coagulation disorders, pregnancy), (2) patients underwent epidural injection in the last six months, (3) inflammatory diseases (rheumatoid arthritis, spondyloarthropathy), spinal infection or malignancy, (4) reluctance to participate in the study, and (5) illiteracy. In addition, all patients were questioned about their socio-demographic characteristics and current symptoms.

\section{Study design and intervention}

This study was designed as a prospective, randomized controlled study. Patients were randomized into two groups. The randomization was performed by the sealed envelope system. The first group was given verbal information and a pre-injection information leaflet; only verbal information was given to the second group. Written and verbal informed consent were obtained from all patients who were scheduled for injection. Pre- and post-injection evalua- 

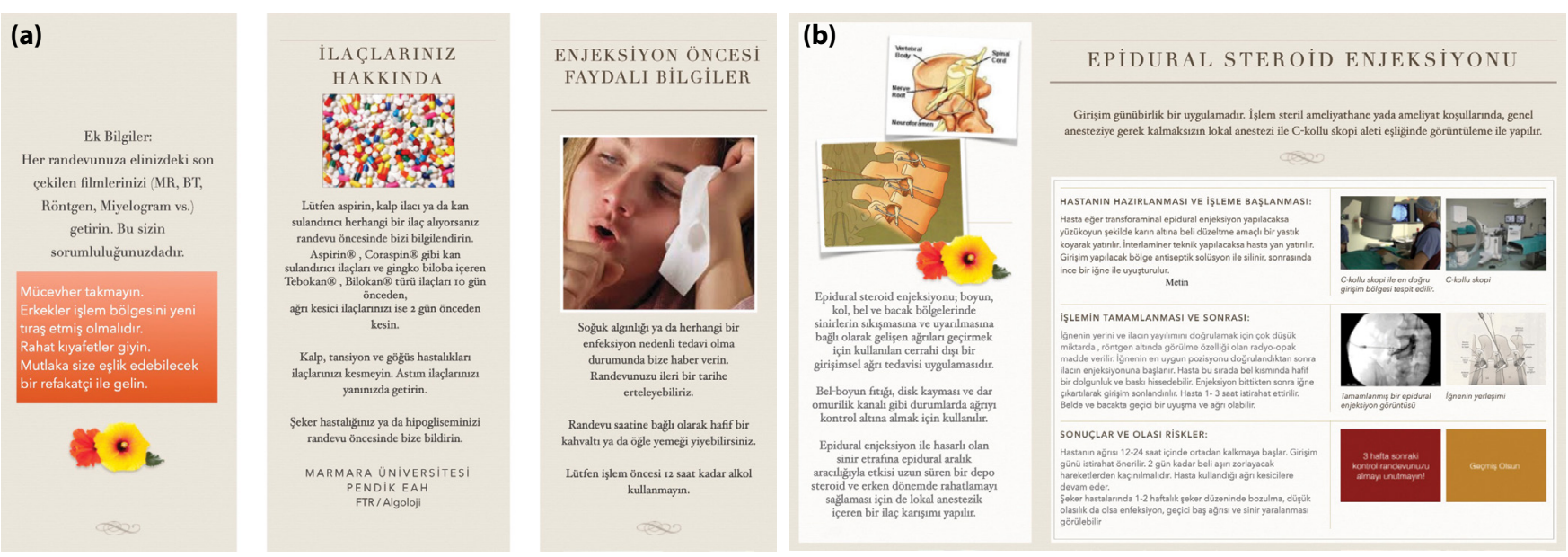

Figure 1. (a, b) Informative leaflet sample.

tions were performed by the investigators who had no knowledge about the groups (control or leaflet group). The study was approved by the institutional review board of (Blind) University (protocol number: 09.2014.0089) and was carried out in compliance with the Helsinki Declaration. Oral and written informed consents were obtained from all participants.

\section{Information leaflet}

The written and visual information leaflet prepared specifically for the patients in the study aims to provide detailed information by clearly outlining the procedure, suggesting what is needed before and after injection (what the patient needs to bring, which suggestions may not apply to particular patients, control visitation day, etc.) and outlining what needs to be applied on or before the injection day. A detailed description of which kinds of patients can be candidates for the injection and every stage of the injection process was explained clearly in the leaflet. In addition, written and visual information about the injection room and the C-arm fluoroscopy used were also given. The information leaflet is shown in Figure $1 a, b$.

\section{Transforaminal epidural steroid injection}

Before the TFESI, the patient was placed in the prone position on the operation table. A pad was placed under the abdomen of the patient to make the spine straight and to obtain the image more clearly. To open the area to be treated and to visualize the facet joint and pars interarticularis better, the $\mathrm{C}$-arm fluoroscopy device was positioned at an angle of $20^{\circ}$ to $30^{\circ}$ obliquely in the $10^{\circ}$ to $15^{\circ}$ craniocaudal direction toward the procedure area. The injection site was sterilized by applying batticon solution 3 times and

covered by a sterile drape. Local anesthetic agent (3 $\mathrm{ml} 2 \%$ prilocaine) was injected into the cutaneous and subcutaneous tissue of the injection site. A 22to 24-gauge 3.5-inch spinal Quincke needle was advanced in the subpedicular area along the 6 o'clock direction under intermittent fluoroscopic visualization. When the epidural space was approached, whether the needle was in the subpedicular area was confirmed by taking a lateral image. After confirming the location of the needle, 1-2 ml of contrast medium was given to ensure that the needle was in the epidural space. After observing that the needle was in the epidural space and there was no vascularity, the mixture of corticosteroid, anesthetic agent, and physiological saline solution ( $80 \mathrm{mg}$ of methylprednisolone acetate, $1 \mathrm{ml}$ of $0.5 \%$ bupivacaine, $1 \mathrm{ml}$ of physiological saline solution) was injected. After the injection, the patient was followed up in the observation room for one hour.

\section{Outcome measures}

\section{Pain and disability assessment}

Pain intensity was measured using a 10-point numerical rating scale (NRS) for low back pain. The low-back disability was evaluated using the Oswestry Disability Index (ODI). The ODI is a survey designed to investigate how lumbar and leg pain affects a patient's daily life. It consists of ten questions interrogating the general life activity of the patient. The patient receives may receive between zero points and five points from each question. Higher scores indicate an increased disability. Accordingly, the percentage of the patient's life activity being affected was calculated. The validity and reliability of the Turkish version of ODI was made by Yakut et al. ${ }^{[10]}$ Before the TFESI, the patient-reported outcomes were recorded with NRS 
Table 1. Patient characteristics and comparison of the demographic data

\begin{tabular}{|c|c|c|c|c|c|}
\hline & \multicolumn{2}{|c|}{$\begin{array}{l}\text { Control } \\
\text { group } \\
(n=95)\end{array}$} & \multicolumn{2}{|c|}{$\begin{array}{l}\text { Leaflet } \\
\text { group } \\
(n=71)\end{array}$} & \multirow[t]{2}{*}{$\mathbf{p}$} \\
\hline & $\mathbf{n}$ & $\%$ & $\mathbf{n}$ & $\%$ & \\
\hline Age Mean $\pm S D$ & \multicolumn{2}{|c|}{$48.82 \pm 13.48$} & \multicolumn{2}{|c|}{$49.09 \pm 13.65$} & ${ }^{1} 0.90$ \\
\hline BMI Mean $\pm S D$ & \multicolumn{2}{|c|}{$28.07 \pm 4.12$} & \multicolumn{2}{|c|}{$28.13 \pm 5.04$} & ${ }^{1} 0.94$ \\
\hline \multicolumn{6}{|l|}{$\mathrm{F} / \mathrm{M}$} \\
\hline Female & 48 & 50.5 & 40 & 56.3 & \multirow{2}{*}{${ }^{2} 0.43$} \\
\hline Male & 47 & 49.5 & 31 & 43.7 & \\
\hline \multicolumn{6}{|l|}{ Injection side } \\
\hline Right & 34 & 35.8 & 25 & 35.2 & \multirow{3}{*}{${ }^{2} 0.81$} \\
\hline Left & 35 & 36.8 & 32 & 45.1 & \\
\hline Bilateral & 26 & 27.4 & 14 & 19.7 & \\
\hline
\end{tabular}

1: Student t Test; 2: Chi-Squared Test; BMI: Body mass index; n: Number of patients; SD: Standard deviation.

and ODI. Usual verbal information for both groups, written and visual information leaflet for leaflet group was given at least 2-hour, before the TFESI. Also, patients completed NRS at 1-hour after the TFESI.

\section{Depression and anxiety assessments}

Before the TFESI, all patients were assessed using the Hospital Anxiety and Depression Scale (HADS) for depression and anxiety symptoms. The evaluation of depression and anxiety of the group who received the information leaflet was done after the leaflet was given to the patients. The HADS is an easy-to-use questionnaire consisting of fourteen questions, with seven questions examining symptoms of depression and seven questions examining symptoms of anxiety. The validity and reliability of the Turkish version was made by Aydemir et al. ${ }^{[1]}$

\section{Statistical analysis}

It was found that 74 individuals for each group (control and leaflet group) must have been recruited to have $80 \%$ power with a $5 \%$ type 1 error level to detect a minimum clinically significant difference of post-information state anxiety, when the average expected value in the first group (with standard information) was 36.1, with a standard deviation of 11.1, and the average expected value in the second group was 42.1 , with a standard deviation of 10.9 (with full information) based on the previous research conducted by Garden et al. ${ }^{[8]}$ that state
Table 2. Comparison of the baseline parameters between the groups

\begin{tabular}{|c|c|c|c|c|c|}
\hline & \multicolumn{2}{|c|}{$\begin{array}{l}\text { Control } \\
\text { group } \\
(n=95)\end{array}$} & \multicolumn{2}{|c|}{$\begin{array}{l}\text { Leaflet } \\
\text { group } \\
(n=71)\end{array}$} & \multirow[t]{2}{*}{$\mathbf{p}$} \\
\hline & $\mathbf{n}$ & $\%$ & n & $\%$ & \\
\hline \multicolumn{6}{|c|}{ Depression } \\
\hline No & 53 & 55.8 & 43 & 60.6 & $0.538^{1}$ \\
\hline Yes & 42 & 44.2 & 28 & 39.4 & \\
\hline \multicolumn{6}{|l|}{ Anxiety } \\
\hline No & 39 & 41.1 & 25 & 35.2 & $0.444^{1}$ \\
\hline Yes & 56 & 58.9 & 46 & 64.8 & \\
\hline ODI & \multicolumn{2}{|c|}{$\begin{array}{c}54.76 \pm 18.18 \\
(54)\end{array}$} & \multicolumn{2}{|c|}{$\begin{array}{c}50.12 \pm 18.72 \\
(48)\end{array}$} & $0.120^{2}$ \\
\hline NRS & \multicolumn{2}{|c|}{$\begin{array}{c}7.74 \pm 1.48 \\
(8)\end{array}$} & \multicolumn{2}{|c|}{$\begin{array}{c}7.37 \pm 1.79 \\
\text { (7) }\end{array}$} & $0.216^{2}$ \\
\hline
\end{tabular}

1: Student t Test; 2: Chi-Squared Test; BMI: Body mass index; n: Number of patients; NRS: Numeric rating scale; ODI: Oswestry disability index.

anxiety was evaluated according to pre-procedural information leaflet in patients undergoing surgery. Taking into account the $10 \%$ patient drop, the minimum number of patients to be included in the study was determined to be 163 .

The data was analyzed using Statistical Package for Social Sciences (SPSS) for Windows 22.0. The histogram and normality plots and Shapiro-Wilk normality test was used for data distribution analysis. Descriptive statistical methods (mean, standard deviation, frequency) were used when study data were evaluated. The Student t-test was used for comparison between both groups of normal distribution parameters, and the Mann-Whitney $U$ test was used for non-normal distribution parameters. The Friedman test was used for intra-group comparisons of non-normal distribution parameters. The chi-square test was used for comparison of qualitative data. A $p$-value of $<0.05$ was considered significant.

\section{Results}

Of the 268 patients evaluated for eligibility in the study, 99 were eliminated because they did not meet the inclusion criteria and 3 were unwilling to participate. The study was conducted on 166 patients, between the ages of eighteen and eighty years, of whom 88 (53\%) were women and 78 (47\%) were men. 


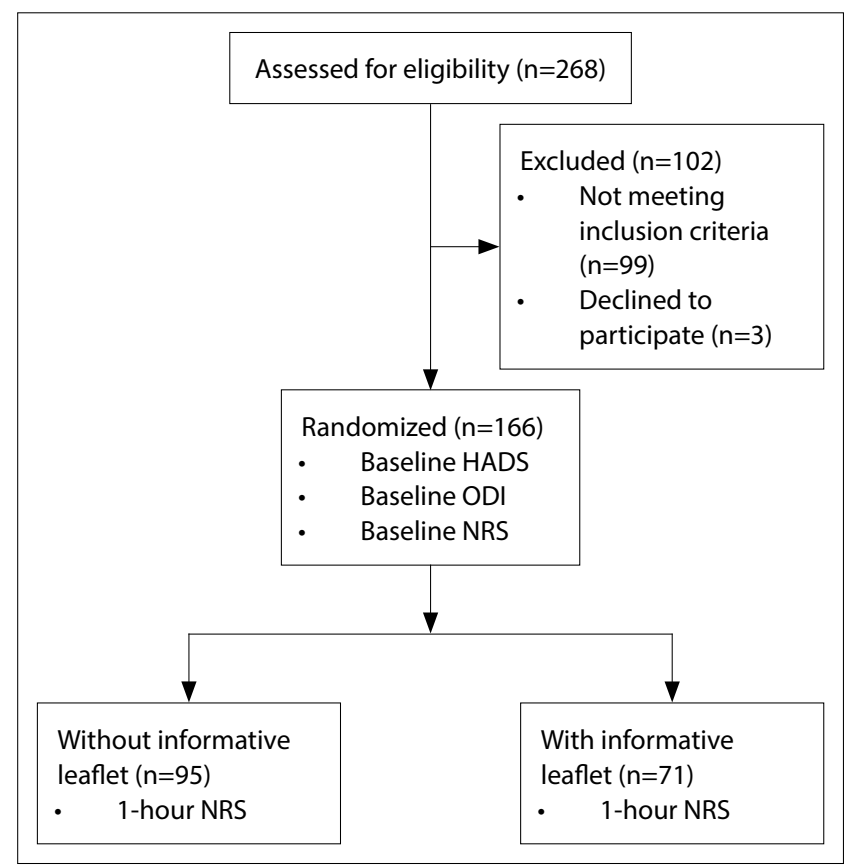

Figure 2. CONSORT diagram of the study.

No major complications were observed (E.g., nerve damage, unceasing hemorrhage, and infection). The first group was given verbal information (control) and the second group was given the verbal information and a detailed information leaflet with written and visual content (leaflet group or LG). The Consolidated Standards of Reporting Trials (CONSORT) Flow Diagram of the study is shown in Figure 2. The demographic characteristics and clinical data of the groups are summarised in Table 1. There was no significant difference in the demographic and clinical characteristics of both groups ( $p>0.05$ ) (Table 1).

There was a decrease in NRS scores in both groups after TFESI at the 1-hour. Both groups benefited from treatment, and there was no significant NRS change difference between the two groups ( $p>0.05$ ) (Fig. 3).

When both groups were compared, no significant difference was observed between the pre-procedural presence of anxiety and depression ( $p>0.05$ ). Pain level and disability scores were similar according to preprocedural evaluation (Table 2 ).

\section{Discussion}

In this study, we proposed to investigate the immediate effect of TFESI on patients who were given detailed information leaflet versus patients who were only given verbal information. TFESI is a useful and usable method for patients with symptomatic lumbar

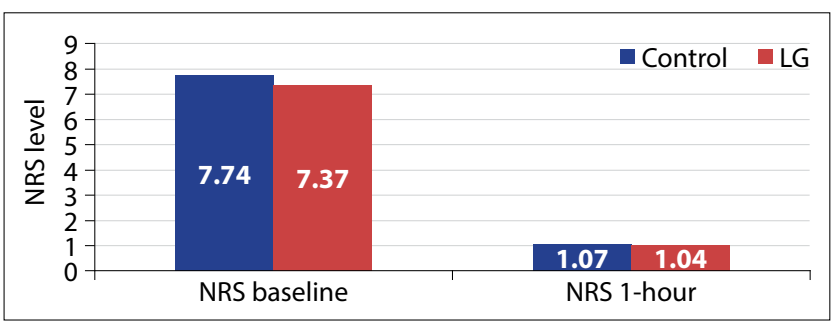

Figure 3. Intra-group immediate pain level change after TFESI. NRS: Numeric rating scale; LG: Leaflet group.

disc herniation with back pain and radicular pain. No significant difference was observed on the immediate pain level in both patient groups (Control and LG).

As in this trial, the positive effect of the TFESI for lumbar radiculopathy treatment on radicular pain and functionality has also been demonstrated in previous studies. ${ }^{[4,12,13]}$ Acute efficacy of TFESI in nonchronic lumbar radiculopathy pain has been demonstrated once again.

Previous studies have shown that inadequate information before the diagnostic tests increases anxiety (such as colposcopy). ${ }^{[14]}$ This higher level of anxiety also increases pain, discomfort during the procedure and causes loss of patients during follow-up. ${ }^{[14]}$ On the other hand, studies are showing that the anxiety has not changed and the information form does not affect the outcome of the treatment procedures. ${ }^{[3,14]}$ Howev$\mathrm{er}$, in the current study, patients were divided into two groups with and without information leaflets. Both groups benefited from the procedure, and there was no difference in disability and pain levels before the procedure in terms of depression and anxiety rates. In a study investigating the importance of patient education before hip surgery, pre-procedural anxiety, and pain levels were shown to be lower in the training group. ${ }^{[7]}$ In another study, the anxiety-reducing effect of pre-operative information leaflets was shown, ${ }^{[9]}$ but the results in similar studies were contradictory. Increased information for patients before surgery may reduce the fear, uncertainty, and anxiety, but may also be ineffective on pre-procedural anxiety. ${ }^{[8]}$ In our study, the informational leaflet did not have a significant effect on pre-procedural anxiety and depression levels. Coudeyre et al. ${ }^{[3]}$ showed that the pre-epidural steroid injection informational leaflet provided patient satisfaction in terms of understanding complications, but did not have a significant effect on anxiety. These results are similar to the results of this study. Providing detailed information about the procedure prior to the 
treatment may increase the patient's anxiety status as it shows the process and severity of the procedure. However, providing a detailed information leaflet about the procedure can also relieve procedure-related or complication-related fear. Therefore, the leaflet may not have had a significant impact on anxiety.

Two important issues should be taken into consideration in transferring information when communicating with patients. The first of these is the personal characteristics of the patients (health status, age, and educational level). The second one is how seriously patients take reading the information.$^{[3]}$ In addition, patients can easily obtain information with today's technology and may not need a detailed information leaflet. With this information, the readability, comprehensibility, and fulfill the needs of a standard information leaflet can be improved over time.

\section{Limitations and strengths of the study}

The study has several limitations that should be noted. First, patients were monitored for short follow-up periods. We thought that the most important effect of the leaflet would be during the treatment or in the acute period after the procedure. Second, minor complications during the procedure and patient satisfaction were not studied. In particular, taking blood pressure measurements and heart rate records of patients during the pre-procedure could provide information about their current status. Also, since the majority of patients did not comment on their educational status, we could not obtain significant findings to correlate the level of education and the patient's attitude towards information.

Despite these results, informed consent is increasingly important. Being one of the first prospective randomized studies to examine the effectiveness of the standard detailed information form for TFESI is the main strength of the study. There was no significant acute effect of the detailed written informational leaflet. Particularly, studies that investigate patient satisfaction are more needed. The importance of detailed information and informed consent is increased every day, and future researchers should clarify this issue.

Ethics Committee Approval: Marmara University Clinical Reasearch Ethics Comittee granted approval for this study (date: 06.09.2014, number: 09.2014.0089).
Conflict-of-interest issues regarding the authorship or article: None declared.

\section{Peer-rewiew: Externally peer-reviewed.}

\section{References}

1. Vassallo T, Mizzi A, Depasquale R, Maher M, Rainford L. The development of patient information leaflets incorporating patient diversity considerations: Varicocele embolisation and fluoroscopy guided joint injection examinations. Radiography (Lond) 2018;24(Suppl 1):S20-7. [CrossRef]

2. Rajasundaram R, Phillips S, Clay NR. Information leaflet used in out-patient clinics: a survey of attitude and understanding of the user. Int J Health Care Qual Assur Inc Leadersh Health Serv 2006;19(6-7):575-9. [CrossRef]

3. Coudeyre E, Poiraudeau S, Revel M, Kahan A, Drapé JL, Ravaud $P$. Beneficial effects of information leaflets before spinal steroid injection. Joint Bone Spine 2002;69(6):597-603.

4. Sariyildiz MA, Batmaz I, Yazmalar $L$, Güneş $M$, Turan $Y$. The effectiveness of transforaminal epidural steroid injections on radicular pain, functionality, psychological status and sleep quality in patients with lumbar disc herniation. J Back Musculoskelet Rehabil 2017;30(2):265-70. [CrossRef]

5. Kim TW, Oh CH, Shim YS, Yoon SH, Park HC, Park CO. Psychopathological influence of lumbar disc herniation in male adolescent. Yonsei Med J 2013;54(4):813-8. [CrossRef]

6. Furman MB, Kothari G, Parikh T, Anderson JG, Khawaja A. Efficacy of fluoroscopically guided, contrast-enhanced lumbosacral interlaminar epidural steroid injections: a pilot study. Pain Med 2010;11(9):1328-34. [CrossRef]

7. Giraudet-Le Quintrec JS, Coste J, Vastel L, Pacault V, Jeanne $L$, Lamas JP, et al. Positive effect of patient education for hip surgery: a randomized trial. Clin Orthop Relat Res 2003;(414):112-20. [CrossRef]

8. Garden AL, Merry AF, Holland RL, Petrie KJ. Anaesthesia information--what patients want to know. Anaesth Intensive Care 1996;24(5):594-8. [CrossRef]

9. Romeo MCM, Muniesa LS. Effects of using an information leaflet in reducing perioperative anxiety and pain in patients undergoing urological surgery. Enfermería Clínica 2014;24(4):233-40. [CrossRef]

10. Yakut E, Düger T, Oksüz C, Yörükan S, Ureten $K$, Turan D, et al. Validation of the Turkish version of the Oswestry Disability Index for patients with low back pain. Spine (Phila Pa 1976) 2004;29(5):581-5. [CrossRef]

11. Aydemir Ö, Guvenir T, Kuey L, Kultur S. Validity and reliability of Turkish version of hospital anxiety and depression scale. Turk Psikiyatri Derg 1997;8(4):280-7.

12. Gharibo CG, Varlotta GP, Rhame EE, Liu EC, Bendo JA, Perloff MD. Interlaminar versus transforaminal epidural steroids for the treatment of subacute lumbar radicular pain: a randomized, blinded, prospective outcome study. Pain Physician 2011;14(6):499-511.

13. Sencan S, Ozcan-Eksi EE, Cil H, Tay B, Berven S, Burch S, et al. The effect of transforaminal epidural steroid injections in patients with spondylolisthesis. J Back Musculoskelet Rehabil 2017;30(4):841-6. [CrossRef]

14. Ketelaars PJW, Buskes MHM, Bosgraaf RP, van Hamont D, Prins JB, Massuger LFAG, et al. The effect of video information on anxiety levels in women attending colposcopy: a randomized controlled trial. Acta Oncol 2017;56(12):1728-33. 